\title{
Classroom Management: A Study on the Training Needs of Primary School Teachers
}

\author{
Faida Imhemid Salem El Warfali ${ }^{1} \&$ Nik Mohd Rahimi Nik Yusoff ${ }^{2}$ \\ ${ }^{1}$ University of Benghazi, Libya \\ ${ }^{2}$ Faculty of Education, Universiti Kebangsaan Malaysia, Malaysia \\ Correspondence: Nik Mohd Rahimi Nik Yusoff, Faculty of Education, Universiti Kebangsaan Malaysia, 43600 \\ UKM Bangi, Selangor, Malaysia. Tel: 603-8921-6241. E-mail: nik@ukm.edu.my, nikmrahimi@gmail.com
}

Received: July 22, 2014 Accepted: November 5, 2014 Online Published: December 21, 2014

doi:10.5539/ies.v7n13p1 URL: http://dx.doi.org/10.5539/ies.v7n13p1

\begin{abstract}
This study aimed to identify the training needs of the in-service primary school teachers in the city of Benghazi, Libya. Data collection involved the administration of a set of questionnaire to 420 teachers and interviews with ten of them. The study found that the most important training needs of the primary school teachers in terms of classroom management were: (i) training on how to improve students' behavior through the development of codes of conduct for the students at the beginning of the school year, (ii) training on efficient time management to achieve the objectives of the classroom session, and (iii) training on means of modifying the abnormal behavior of the students. Data from the interview revealed some of the methods used by the participants on addressing issues and challenges faced in handling the students. The study supports the importance of organizing classroom management training to in-service primary school teachers to help them manage the classroom effectively.
\end{abstract}

Keywords: classroom management, training needs, teacher education, teacher training, professional development

\section{Introduction}

Since teachers are identified to be the cornerstone of any reform or development in educational system, the reform and development in Libya has to start with them in terms of their selection, preparation and training. The philosophy of educational systems and methods cannot lead to the desired development in the absence of highly qualified teachers. As Badri (2006) stated, as far as educational system in Libya is concerned, teachers are at the center of concern in the system. Therefore, some institutions have been established in preparing them to improve and develop the educational process in the country. Teachers are considered as a cornerstone and the most prominent element in the educational process and their interaction in schools will build and accumulate their knowledge, values, attitudes, skills and experience.

Some studies indicated that $60 \%$ of the success in all dimensions of the educational process is primarily attributed to the teachers alone, while the combination of other factors including administration, curricula and the school facilities contributed to the rest 40\% (Abu Russ, 2011; Enzi, 2007). These studies suggested the importance of teachers' role in producing high quality students. The 2020 report of the Department for Education and Employment, Britain advocated that education can inherit treasures of knowledge to all of us. On the other hand, with the expansive growth in science and technology in the twenty first century, knowledge and skills are considered as the principal keys to success (Al hila, 2002). The outstanding teachers who employ effective teaching methods and approaches are the key to achieve high quality education which is tightly associated with teachers who possess personal, technical and professional skills.

The process of identifying the right training needs of the teachers is regarded as the first step in order to plan suitable programs for school teachers' in-service training, to the extent that it is a necessity for every successful training process. Furthermore, the identification of the teachers' training needs is the optimum means of specifying the extent of knowledge, skills, directions and experiences needed to promote development and raising the professional competency of the teachers. 


\section{Methods of the Study}

This study is based on the following question: What are the in-service training needs of primary school teachers in classroom management? In order to answer the question, this study used the combination of the descriptive approach using a set of questionnaire and the qualitative method through interviews. According to the official records of the Office of Measurement and Evaluation at the Secretariat of Education and Scientific Research, the population of all primary school teachers in the city of Benghazi is 6848 . Therefore, a total of 420 samples was selected randomly which was based on the sample size determination equation as suggested by Krecjie and Morgan (1970). In addition, ten of respondents were interviewed to provide further explanation on the aspect of the training need based on the quantitative results.

The structured questionnaire was constructed by the researcher and it has been referred to the three of the experts in the field for the constructs validation. They have given their agreement for the questionnaire. The questionnaire also went through the reliability test by using Cronbach Alpha and the coefficient showed 0.89. Meanwhile, the interview protocol consists of 16 questions (as in the questionnaire) aimed to get detailed explanation from what they have ticked in their questionnaire.

\section{Results and Discussions}

The researchers sought an answer to the main question of the study by using appropriate statistical methods and then analyzed the results. This part of the study was made up of 16 items which indicated the training needs of all respondents. These items as well as respondents' feedback are illustrated in Table 1.

Table 1. Frequency distribution of teachers' training needs for classroom management

\begin{tabular}{|c|c|c|c|c|c|c|c|}
\hline & & $\begin{array}{l}\text { Less } \\
\text { needed } \\
1\end{array}$ & 2 & 3 & 4 & $\begin{array}{l}\text { Most } \\
\text { needed } \\
5\end{array}$ & Mean \\
\hline 1 & Training to maintain order in normal circumstances. & $1.90 \%$ & $1.90 \%$ & $16.10 \%$ & $34.30 \%$ & $46.00 \%$ & 4.2 \\
\hline 2 & $\begin{array}{l}\text { Training on methods of involving the students in } \\
\text { planning educational activities. }\end{array}$ & $1.40 \%$ & $5.00 \%$ & $24.8 \%$ & $35.2 \%$ & $33.6 \%$ & 3.9 \\
\hline 3 & $\begin{array}{l}\text { Training to engage students in the implementation of } \\
\text { some of the educational activities. }\end{array}$ & $1.00 \%$ & $3.80 \%$ & $22.4 \%$ & $35.7 \%$ & $37.1 \%$ & 4 \\
\hline 4 & $\begin{array}{l}\text { Training to maintain order within the class in } \\
\text { emergency situations. }\end{array}$ & $1.60 \%$ & $5.00 \%$ & $12.9 \%$ & $29.3 \%$ & $51.2 \%$ & 4.2 \\
\hline 5 & Practice of active management in the classroom. & $2.10 \%$ & $6.00 \%$ & $20.0 \%$ & $38.3 \%$ & $33.6 \%$ & 4,0 \\
\hline 6 & $\begin{array}{l}\text { Training on dealing with students in a democratic } \\
\text { way. }\end{array}$ & $1.90 \%$ & $3.60 \%$ & $20.0 \%$ & $32.4 \%$ & $42.1 \%$ & 4.1 \\
\hline 7 & $\begin{array}{l}\text { Practice to manage the time effectively to achieve the } \\
\text { lesson objectives. }\end{array}$ & $2.40 \%$ & $2.60 \%$ & $11.9 \%$ & $27.6 \%$ & $55.5 \%$ & 4.3 \\
\hline 8 & $\begin{array}{l}\text { Training on the organization of physical environment } \\
\text { in classroom. }\end{array}$ & $4.70 \%$ & $11.00 \%$ & $29.8 \%$ & $32.4 \%$ & $22.1 \%$ & 3.6 \\
\hline 9 & $\begin{array}{l}\text { Training to use methods that initiate classroom } \\
\text { interaction among students. }\end{array}$ & $1.80 \%$ & $4.80 \%$ & $21.2 \%$ & $37.4 \%$ & $34.8 \%$ & 4,0 \\
\hline 10 & $\begin{array}{l}\text { Training to use methods that initiate classroom } \\
\text { interaction between students and teachers. }\end{array}$ & $2.60 \%$ & $4.00 \%$ & $15.0 \%$ & $39.5 \%$ & $38.8 \%$ & 4.1 \\
\hline 11 & $\begin{array}{l}\text { Training on applying new approaches and methods for } \\
\text { classroom management that enable students to use } \\
\text { new forms of learning like self-learning. }\end{array}$ & $3.00 \%$ & $9.30 \%$ & $22.9 \%$ & $31.70 \%$ & $33.1 \%$ & 3.8 \\
\hline 12 & $\begin{array}{l}\text { Training on the process of determining behavior } \\
\text { which indicates students' attention. }\end{array}$ & $1.70 \%$ & $3.10 \%$ & $15.7 \%$ & $35 \%$ & $44.5 \%$ & 4.2 \\
\hline 13 & $\begin{array}{l}\text { Training to improve student's behavior through the } \\
\text { development of codes of conduct for students starting } \\
\text { from the beginning of the school year. }\end{array}$ & $1.40 \%$ & $3.80 \%$ & $8.8 \%$ & $27.9 \%$ & $58.1 \%$ & 4.4 \\
\hline
\end{tabular}




\begin{tabular}{|c|c|c|c|c|c|}
\hline $\begin{array}{l}\text { Training to modify different types of behavior within } \\
\text { the behavior in emergency situations. }\end{array}$ & $1.70 \%$ & $5.00 \%$ & $20.5 \%$ & $34.5 \%$ & $38.3 \%$ \\
\hline $\begin{array}{l}\text { Training on how to modify inappropriate behavior } \\
\text { towards students. }\end{array}$ & $1.50 \%$ & $4.00 \%$ & $12.6 \%$ & $27.4 \%$ & $54.5 \%$ \\
\hline $\begin{array}{l}\text { Training on the use of reward and punishment } \\
\text { according to the educational and psychological } \\
\text { origins. }\end{array}$ & $2.90 \%$ & $3.80 \%$ & $15.2 \%$ & $30.7 \%$ & $47.4 \%$ \\
\hline
\end{tabular}

Table 1 shows that the training needs number 13, namely training to improve students' behavior through the development of the codes of conduct for pupils at the beginning of the school year was ranked as the most priority training requirement for the classroom management by the majority of the respondents ( 244 out of 420 teachers; i.e., $58.1 \%$ of the respondents).

However, interviews with teachers showed that as far as item number 13 is concerned, teachers preferred not to implement the codes of conduct at the beginning of the school year, but rather with the passage of time and after gaining the pupils' trust. They stated that they do not use the codes of conduct at the beginning of the school year, but rather some time later after identifying the backgrounds of the pupils and the behavioral problems that they may demonstrate. The teachers illustrated that they attempt to find suitable methods to handle the behavioral problems they encounter with and they stressed that gaining the students' trust is the most important issue for success of the particular behavior improvement techniques.

A total of 233 teachers $(55.5 \%)$ agreed that item number 7 which is training to manage the time effectively to achieve the lesson objectives as the second most important needs. Meanwhile, item number 15 which is training on how to modify student's inappropriate behavior was ranked number three with the consensus of 229 respondents $(54.5 \%)$.

The three training needs which were ranked fourth, fifth and sixth were four items, namely: items 4 (Training on maintaining order within the class in emergency situations), item 16 (Training on the use of reward and punishment according to the educational and psychological origins), item 1 (Training on the maintenance of order in normal circumstances), and item12 (Training on the process of determining behavior, which indicates the attention of students). The percentages of teachers who identified these items to have these priority rankings were $51.2 \%, 47 \%, 46.00 \%$ and, $44.5 \%$.

The training needs number (6) (Training on dealing with students in a democratic way) and (10) (Training to use the methods that allow the classroom interaction between students and teacher) were at fourth ranking from the perspective of teachers, the percentages of teachers who identified these items to have these priority rankings were $(74.5 \%),(78.3 \%)$ and $(78.1 \%)$.

Interviews with the teachers regarding item number 10 (Training to use methods that initiate classroom interaction between students and teachers) revealed that most of the respondents believed that the methods used in the interactions between students and teachers in the classroom are classical methods that mainly take in the forms of dialogue, or embodiment of historical figures or reviews.

The training needs number (5) (Practice of active management in the classroom), (9) (Training to use methods that initiate classroom interaction among students), (14) (Training to modify different types of behavior within the behavior in emergency situations) and (3) (Training to engage students in the implementation of some of the educational activities) were at fifth ranking from the perspective of teachers, The percentages of teachers who identified these items to have these priority rankings were $(72,8 \%),(72,8 \%),(72,2 \%),(71,9 \%)$.

With regard to item number 3, interviews data indicated that teachers believed that students are already involved in the implementation of certain educational activities and discussions. Furthermore, the involvement of students in the implementation of activities depends on the duration of the session which is usually 45 minutes. Meanwhile, it becomes a common practice to use the last 10 minutes of the lesson for reviewing process as well as question and answer using the dialogue approach. The interviewees also highlighted that item number 9 (Training to use methods that initiate classroom interaction among students) used talk and chalk methods.

The interviewed teachers highlighted that as far as instrument item number 9 (Training to use the methods that allow the classroom interaction between students themselves) is concerned, the methods used in allowing classroom interaction between the students are the classic, rather than modern, methods. 
The training needs number two which is training on methods of involving the students in planning some educational activities was at sixth ranking from the perspective of teachers. It received 177 points out of 420 (42.1\%). However, the teachers disclosed in the interviews that involving students in planning for some educational activities can be achieved via good relationship between the teacher and pupils through the style of discussions, dialogue, and embodying historical characters.

Item number 11 addressed training on applying new approaches and methods for classroom management that enable students to use new forms of learning like self-learning. It was ranked seventh in importance (33.1\% of the samples). In line with this, the teachers expressed during interviews that (i) the methods of teaching used are quite traditional, e.g., discussions and revisions of lessons, and new approaches like the self-learning are not being practiced; and (ii) modern methods of organizing the classroom and maintaining order in it such as time management and self-regulated learning are practically non-employed.

As a final remark, the findings of this study were similar to other previous studies (Jabri, 2002; Tarawneh, 2003) which indicated that there are the needs for training for the Libyan primary schools. On contrary, this study identified specifically the training needs for them compared to the previous studies which just stated in general the training needs.

In general, based on the results of the questionnaire and interview, all items related to training aspects were very much needed by primary school teachers. This situation was due to the following six main factors. First, the classroom environment is one of the pillars of the educational process wherein interactions among learners and with teachers and as well as administrative staffs have major impacts on the manner how teachers deal with the students. A democratic management style which allows students freedom to express their views and to participate in classroom management, dominance of relationships based on mutual respect and freedom of opinion, encouragement of views and new ideas that do not conflict with religious texts, application of an Islamic education and evaluation system, and involvement of assumptions and hypotheses related to the relationship between students and teachers are all factors contributing to a conducive educational atmosphere (Zoubi, 2009).Thus it is very important that these issues being exposed to the teachers.

Second, the results of this study also stress that the teachers' successful management of the class constitutes a basis for teachers' success in performing their jobs, otherwise they cannot perform satisfactorily. Second, the results of this study also stress that the teachers' successful management of the class constitutes a basis for teachers' success in performing their jobs, otherwise they cannot perform satisfactorily. The management of the classroom is one of the important determinants of effective teachers as well as the important determinants of the behavior of students and teacher in the classroom (Enzi, 2007).

Third, the approaches of classroom management and maintenance of order were varied from one teacher to another. We find that non-experienced teachers exhibit their worry related to the classroom management. Nonetheless, this is a natural reaction of people who are in the leadership role position. On the other hand, expert teachers in classroom management are usually more confident and decisive compared to non-experienced teachers. Therefore, classroom management is the biggest challenge that teachers face especially to novice teachers. In other words, without proper classroom management effective lesson cannot be achieved. Therefore, it can be concluded that classroom management in the educational process can be viewed as one of the most important determinants of the effective teaching and learning (Jaber, 1998; Aziz, 2007; Sammie, 2005).

The fourth factor is time management. It is considered as an available resource to be invested efficiently. Time management is an important dimension to be invested in the present and to seriously consider taking advantage for the future planning. It should be invested effectively and the loss in it should be reduced to the minimum possible (Struck, 2004).

The fifth factor is that interviews with teachers showed that they considered the methods used in applying classroom interaction among students were ineffective methods, e.g., dialogue or embodiment of historical characters or reviews. They also highlighted that the classroom session duration does not provide teachers with enough time to diversify teaching methods in order to allow interactions among students and between students and teachers.

The sixth factor is that the results of this study also underlined that the inappropriate working conditions which tie teachers with high-intensity classes, the large amount of academic materials, and somewhat short session timeframe making teachers unable to perform their duties effectively. Therefore, these situations make them feeling helpless, reducing their performance, and thus largely hinder their positive interaction with students. 


\section{Conclusion}

Based on the findings of the study, the Libyan primary school teachers are indeed need in-service training to refresh as well update their teaching methods in order to be effective teachers. In addition, the identification of the training needs of primary school teachers in a scientific way would be the first and main step as well as the backbone to constitute the training process. In light of the findings of this study, the researchers recommend: a) Arrangement of sessions and seminars for teachers in classroom management; b) Organizing in-service training for teachers according to their actual training needs as being found in this study; c) Integrating the pre-service with the in-service training, and establishing an evaluation mechanism to coordinate the efforts and training programs of the teacher training colleges and the Secretariat of Education; d) Creating a system of material and moral incentives to support teachers' engagement in training programs during their teaching service; and e) Activating exchanging visit programs between teachers in order to share the classroom management techniques that they have accumulated over the years, particularly regarding comprehension of the conditions of educational attitude, the giving of the classroom environment, and means how to manage students' community.

\section{References}

Abu Russ, F. M. H. (2001). Identification of training needs for teachers of grades four core first public school district of Nablus (M.A. thesis, Faculty of Education, An-Najah National University, Palestine).

Al hila, M. M. (2002). Classroom teaching skills. Jordan: Dar Al-Maris Li Al-Tibaah wa Al-Nasr.

Aziz, A. (2007). Classroom management and teacher development. Alexandaria: Dar Al-Jamiah Al-Jadidah.

Badri, A. R. M. (2006). Teacher preparation and rehabilitation of the education system in the Great Jamahiriya and the reality and prospects. Paper presented The Islamic Organization for Education Scientific and Cultural Organization ISESCO and the World Islamic Call Society, University Press Aqarion, Part II, Benghazi, Libya.

Enzi, B. (2007). The development of competencies the teacher in the light of quality standards in public education. Paper submitted at The Fourteenth Annual of the Saudi Association of Psychological Science and Education, King Saud University, Saudi Arabia.

Jaber, A. H. (1998). Teaching and learning, the theoretical foundations and effective strategies. Cairo: Dar Al-Fikr Al-Arabi.

Jabri, S. (2002). The training needs of social studies teachers in secondary schools in the Sultanate of Oman. M.A. Faculty of Education, University of Qatar.

Krejcie, R. V., \& Morgan, D. W. (1970). Determining sample size for research activities. Educational and Psychological Measurement, 30(3), 607-610.

Sammie, A. (2005). Teacher preparation and development and training. Jordan: Dar Al-Fikr.

Struck, R. (2004). Studies in Educational Administration. Jordan: Dar Wael Li Al-Nas.

Tarawneh. (2003). A field study on the training needs of teachers in raising the banner of the southern Jordan Valley. Journal of Educational and Psychological Sciences, 4(3), 55-68.

Zoubi, M. (2009). The degree of teachers of Islamic education in the secondary stage of the methods to encourage creative thinking in the province Muqrin Jordan, from their point of view. Journal of Umm Al-Qura for Educational and Psychological Sciences, 1(1), 14-30.

\section{Copyrights}

Copyright for this article is retained by the author(s), with first publication rights granted to the journal.

This is an open-access article distributed under the terms and conditions of the Creative Commons Attribution license (http://creativecommons.org/licenses/by/3.0/). 